\title{
Interactions between a natural food web, shellfish farming and exotic species: The case of the Bay of Mont Saint Michel (France)
}

\author{
Arbach Leloup F. ${ }^{a}$, Desroy N. ${ }^{b}$, Le Mao P. ${ }^{b}$, Pauly D. ${ }^{c}$ Le Pape O. ${ }^{a_{*}}$ \\ ${ }^{a}$ Agrocampus Rennes, Laboratoire d'écologie halieutique, 65 rue de St Brieuc, CS 84215, 35042 \\ Rennes, France \\ ${ }^{\mathrm{b}}$ IFREMER, laboratoire côtier Environnement Ressources, 2 bis rue Grout Saint Georges, BP 46, \\ 35402 Saint-Malo Cedex, France \\ ${ }^{\mathrm{c}}$ Fisheries Centre, University of British Columbia, 2202 Main Mall, Vancouver BC V6T 1 Z4 Canada \\ *: Corresponding author : olivier.le_pape@agrocampus-rennes.fr
}

\begin{abstract}
To ensure sustainable uses of the coastal zone, an integrated ecosystemic approach and ecosystem models are required to frame ecological processes and evaluate environmental impacts. Here, a mass-balance trophic (Ecopath) model of the Mont Saint Michel Bay (MSMB) was developed, to analyze the bay's functioning as an ecosystem. This bay, intensively exploited by fishing and for shellfish farming, is also suffering from the proliferation of the gastropod Crepidula fornicata, an exotic species.

The MSMB model has 18 compartments, from the primary producers to top predators, and emphasizes the large biomass of filter feeders. The model identified the MSMB as a highly productive ecosystem controlled largely from the bottom-up, and strongly impacted by huge biomasses of filter feeders. However, the low transfer efficiency rates imply that a large part of the primary production is not transferred upward to higher trophic levels, but is lost in high hydrodynamic exchanges and in the trophic impasse represented by a large biomass of Crepidula fornicata.
\end{abstract}

Keywords: Ecopath; trophic model; shellfish farming; invasive species; Crepidula fornicata; Mont Saint Michel Bay 


\section{INTRODUCTION}

Coastal areas are productive ecosystems that host a large part of the world's living marine resources and have the highest biological diversity of any part of the sea (Costanza et al., 1997). Despite these ecological (Beck et al., 2001; Hugues et al., 2005), economical and social (Balmford et al., 2002) largely irreplaceable benefits, these ecosystems have been increasingly subjected to a large number of human pressures, leading to major environmental problems: eutrophication and pollution, over-exploitation, invasions by alien species, etc. (Costanza, 1999; Antunes and Santos, 1999; Hugues et al., 2005).

In this context, ecosystem models may be used as a tool for resolving patterns, indicative of the key ecosystem responses (Fulton et al., 2005). Using such models, analyze of the effects of disturbance and measure of the ecosystem stability and resilience become possible (Perez-Espana and Arreguin-Sanchez, 2001). Within the last few decades, the number of ecosystem models in existence has rapidly grown (Fulton et al., 2003), especially trophic or food web models, notably through the wide availability and acceptance of the Ecopath with Ecosim (Ewe) software (Christensen and Walters, 2004).

Here, Ecopath was used to organize information on the functioning of the food web of the Mont Saint Michel Bay (MSMB), located on the north coast of France. The site is famous for its abbey, built on a hill in the intertidal zone, so much that both the buildings and the vast productive mudflats surrounding it have been recognized for their cultural and ecological interest and, since 1979, is listed in the World Heritage Sites (UNESCO). The MSMB hosts intensive shellfish farming enterprises. Also, for the last decades, it has been facing an invasion of the American slipper limpet Crepidula fornicata (Blanchard, 1997). Measures designed to mitigate these various problems became unavoidable to ensure the conservation of wildlife and associated habitats (Lefeuvre and Bouchart, 2002), and the sustainable development of local economical activities (e.g. tourism, shellfish farming, fishing; Le Mao et al., 2004). Therefore the MSMB was selected, in 2001, as a study site by the French national program of coastal environment (PNEC).

The present study, carried out in the framework of the PNEC, examined the trophic functioning of the MSMB with regards to human activities and recent environmental changes. The ultimate objective was to analyze different interactions between the biological components of the MSMB, and to assess the values of consumption and production fluxes of its food web. An Ecopath model, representing a mass-balance budget of production, consumption and fishing in the food web was constructed. It considers all functional groups in this system, from primary producers to apex predators, including the large biomass of natural, farmed and exotic filter feeders. Information on ecosystem structure and function provided by inferred biomass transfers between functional groups can then be used to evaluate the likely impact of changes in the abundance of selected groups, and examine how such changes are impacting the whole ecosystem via different links of the food web (Ulanowicz, 1986).

\section{MATERIALS AND METHODS}

\subsection{Study site}

The MSMB is located in France, in the western part of the English Channel $\left(48^{\circ} \mathrm{N}\right.$ $1^{\circ} 40^{\prime} \mathrm{W}$; Fig.1). This bay is a semi-diurnal macrotidal system characterized by the second highest tidal range in Europe (10-11 m on average, with a maximum of $15.5 \mathrm{~m}$ ). The intertidal zone covers $250 \mathrm{~km}^{2}$ and includes $210 \mathrm{~km}^{2}$ of mudflats and $40 \mathrm{~km}^{2}$ of salt marshes.

The MSMB is host to a high biodiversity (Lefeuvre and Bouchard, 2002), notably:

- $\quad$ one of the largest salt marshes of the French coast; 
- $\quad$ one of the main nurseries of the English Channel coast for many fish species of commercial interest (Lafaille et al., 2000) such as sea bass (Dicentrarchus labrax), whiting (Merlangius merlangius), flatfishes (common sole Solea solea and plaice Pleuronectes platessa), clupeids (Sardina pilchardus, Clupea harengus and Sprattus sprattus), and elasmobranchs (Raja spp);

- $\quad$ thousands of over-wintering birds and of birds resting while on their migrations;

- $\quad$ honeycomb reef-like structures built by the polychaete Sabellaria alveolata.

This site also hosts activities such as tourism, fishing and shellfish farming (Le Mao et al., 2004). Three bivalves are farmed (Fig.1): (1) the Japanese oyster (Crassostrea gigas) in the intertidal mudflat of Cancale Bay (about 345 ha), (2) the European flat oyster (Ostrea edulis), farmed in the subtidal domain (880 ha), and (3) the common mussel (Mytilus edulis) reared on poles arranged in linear rows on the intertidal mudflat (total length of the rows: $272 \mathrm{~km}$ ). The American limpet, Crepidula fornicata, which was introduced about sixty years ago, is now increasingly found, and currently represents the highest biomass of filter feeders within the bay (Blanchard and Ehrhold, 1999; Blanchard, 1997; Loomis and VanNieuwenhuyze 1985).

\subsection{Model approach}

A mass-balanced trophic model was constructed using EwE (Christensen and Walters, 2004). The core Ecopath routine of EwE, derived from Polovina (1984), was applied to balance the energy budget of the different compartments of the system. The model is structured around a system of linear equations for ensuring mass-balance, which can be expressed (Christensen and Walters, 2004) as:

$$
B_{i} \times(P / B)_{i} \times E E_{i}=Y i+\sum_{j}^{n} B_{j} \times(Q / B)_{j} \times C R_{i j}
$$

where: for $\mathrm{i}$ equal to 1 to $\mathrm{n}$ functional groups and $\mathrm{j}$ equal 1 to $\mathrm{n}$ predators, $\mathrm{B}$ is the biomass in a given period of time; $\mathrm{P} / \mathrm{B}$ the production/biomass ratio, which is equivalent to the instantaneous rate of total mortality, Z, under equilibrium (Allen, 1971); EE the ecotrophic efficiency (the fraction of production consumed, fished or exported out the system); Y the fishery yield; $\mathrm{Q} / \mathrm{B}$ the consumption/biomass ratio and $\mathrm{CR}_{\mathrm{ij}}$, the fraction of $\mathrm{i}$ in the diet of $\mathrm{j}$.

Ecopath sets up a system containing as many linear equations as groups present within a system (n). The model can estimate one of the four parameters (n equations for $n$ unknown parameters) as long as any three of these parameters are known, viz: $B, P / B, Q / B$ or EE.

After the missing parameters have been estimated (with respect to the mass-balance between groups), consumption by predators can be described by the energy balance equation:

Consumption $=$ production + respiration + unassimilated food

\subsection{Input data and model structure}

The study area of the model included $380 \mathrm{~km}^{2}$ of subtidal domain and $210 \mathrm{~km}^{2}$ of intertidal mudflats (Fig. 1). To simplify the model, the salt marshes, connected to trophic network in the bay by the organic matter exported to the tidal system (Lafaille et al., 1998), were included in the model only as imported production.

The food web of the MSMB was described through 18 trophic groups, with the grouping of taxa being based on their having similar trophic properties (preys, predators, turnover rate; Christensen and Walters, 2004). This resulted in two primary producer compartments (phytoplankton and microphytobenthos), three groups of cultivated filter feeders (European flat oyster, Japanese oyster and common mussel), Crepidula fornicata, zooplankton, meiofauna, small fishes (small species and other juvenile fish), three groups of macrobenthic 
fauna exploited by fisheries (carnivorous and necrophagous macrobenthic fauna, intertidal and subtidal filter feeders), mullets, three groups targeted by fisheries (cephalopods, large crustaceans and adult fishes), birds and marine mammals (Table 1).

The major part of data related to biomass, production and consumption (Table 2) were collected from studies conducted within the framework of the PNEC on the MSMB during the reference year 2003 (Table 1), taken as reference because several sampling surveys were performed in the bay during that year. When they were not available from this program, data were collected from various other sources (Table 1), particularly a model developed on the western Channel (Stanford and Pitcher, 2004). Commercial yields were taken from producer statistics for all cultivated species and from official records on statistical rectangle 28E6 of the ICES system, used for European fisheries data collection. Diet compositions (Table 3) were compiled from available literature but mainly from expert knowledge, after discussion with the specialists who provided survey data (Table 1). Biomasses for each group are averaged on an annual period : if a group (as cephalopods) is present only during a part of the year, and eats elsewhere during the rest of the time, its biomass when present is multiplied by the proportion of time of presence to estimate the average annual biomass. It is the reason why no imported food is mentioned in the diet matrix (except for detritus that include organic matter coming from the saltmarshes). Trophic fluxes between the different compartments of the trophic model were estimated in tonnes $(\mathrm{t})$ of wet weight per $\mathrm{km}^{2}$.

\subsection{Network analysis}

Once the model was balanced, various parameters and indices were generated using the EwE software (Christensen and Walters, 2004). Trophic interactions between groups and the effects of exploitation were compared using EE, trophic levels (TL, computed from the mean TL of prey +1 ; Christensen and Pauly, 1998), consumption rates, predation mortality and the primary production required (PPR) to sustain consumption by the various compartments of the model, and the extraction by humans.

Direct and indirect trophic interactions were analyzed using the mixed trophic impact routine of EwE, inspired by the Leontief matrix (Ulanowicz and Puccia 1990), and which reflect both the impact of prey over their predators and of predators over their preys (Pace et al., 1999).

Finally, the system was examined as a whole using the model's global parameters. With Ecopath, functional groups are aggregated into discrete trophic levels sensu Lindeman (1942) as suggested by Ulanowicz (1995), which allows estimation of flows to detritus and upper trophic levels, and of transfer efficiencies. Some network attributes (Ulanowicz, 1986; Ulanowicz and Kay, 1991) and flow indexes were analyzed to describe holistic properties of the system, i.e., total system throughput ( $\mathrm{T}$, sum of all flows through all compartments), Finn's (Finn, 1976) cycling index (FCI, fraction of ecosystem's throughput that is recycled), and Finn's mean path length (FMPL, average size of the path length following for these transfers). The ratio of Net Primary Production to Total Biomass (PP/B) and to Total Respiration (PP/R), was also examined, as it is an important index of system maturity (Odum, 1969). 


\section{RESULTS}

\subsection{Balancing the model}

The Ecopath equation (1) states that each group must be mass-balanced, i.e. for one group, catches, consumption, biomass accumulation and export must not exceed production. Balancing an Ecopath model requires to adjust the input parameters such that none of the EE values exceeds 1 (Christensen and Walters, 2004; Kavanagh et al., 2004).

Here, the biomasses of many predator groups (cephalopods, large shellfishes, carnivorous and necrophagous macrobenthic fauna, adult fishes and small / juveniles fishes) were preliminary adjusted according to expert estimates. A first attempt at balancing the model showed that demand from these predator groups exceeded the production of most prey groups (meiofauna, carnivorous and necrophagous macrobenthic fauna, intertidal and subtidal filter feeders). Thus, to achieve mass-balance, an ecotrophic efficiency of 0.9 was applied to these groups, and the biomass of predator groups targeted by fisheries was left to be estimated by the model (Table 2).

\subsection{Trophic structure of the MSMB}

\subsubsection{A large proportion of filter feeders}

Input values and output estimates after balancing the model were summarized in Table 2 and ecosystem statistics in Table 4. The MSMB is characterized by a high productivity, with an overall production of about $4600 \mathrm{t} \cdot \mathrm{km}^{-2} \cdot \mathrm{year}^{-1}$, and the large biomass of filter feeders $(65 \%$ of total biomass), with Crepidula fornicata as most dominant species (51\% of total biomass). Figure 2a, representing biomasses at different trophic levels, illustrates that there are a substantial lower biomass above the filter feeders $(\mathrm{TL}=2)$.

\subsubsection{Contrast in efficiencies of trophic transfers}

In the model, the productions (Fig. 2b) and EE values (Table 2) showed a wide range of variation, reflecting the unequal trophic roles of various compartments.

First, a large break in the pyramid of production is observed between TL 1 and 2 (6\%), indicating that little of the primary production in the system is utilized. This is matched by low EE values for phytoplankton and microphytobenthos, which indicates that only a small proportion of their production is grazed within the water column, or in the benthic domain.

In contrast, in the next step of the trophic chain (TL2/TL3), the transfer efficiency is quite high (18\%). This corresponds to high values of EE for farmed and 'natural' inter- and subtidal filter feeders, whose production is largely used by shellfish farming ( $70 \%$ of the mortality for oysters and mussels) or consumed by predators (89\% of the mortality of 'natural' filter feeders is caused by predators).

The slipper limpets (Crepidula fornicata) is the exception: only 14\% of its production is utilized by higher trophic-level animals and the fisheries. Moreover, even this is too high, as the catch of slipper limpets is discarded as it is due to dredging operations to limit its extend. The consumption of primary production by slipper limpets is 4 times higher than for cultivated mollusks. When the surface areas covered by the organisms are taken into account (163 $\mathrm{km}^{2}$ covered by Crepidula fornicata versus $238 \mathrm{~km}^{2}$ for shellfish farming), the impact of farmed shellfish remains 2.5 times lower than those due to the slipper limpet. Requiring the highest PPR in the model (17\%), slipper limpets appear as a large trophic impasse in the system: Although this species represents $41 \%$ of the total consumption of primary production and detritus, its trophic efficiency when discards are removed is lower than $3 \%$.

Hence, in the MSMB, the trophic chain is shorten at TL 2 by two different processes, extraction by shellfish farming but, mainly, large production of slipper limpets, not exploited by higher trophic levels (Fig. 3). 
Finally, in the residual natural trophic chain, transfers to top predators is efficient (12\%), as also indicated by high EE values.

\subsubsection{Influence of shellfish farming on yields}

PPR for current total catches $\left(15.9 \mathrm{t} \cdot \mathrm{km}^{-2} \cdot \mathrm{year}^{-1}\right)$ correspond to $15 \%$ of the net primary production; the 'catch' has a mean trophic level of 2.11. This low value is due to the intensity of shellfish farming, which contributes the major part withdrawals by humans. However, the trophic role due to fishing activities proper is far more important than that due to shellfish farming: the PPR to sustain fishing activities is 7 times higher than for shellfish farming.

\subsubsection{Convergent signals indicating a bottom-up, productive immature system}

Results of Leontief matrix routine underline the positive impacts of phytoplankton and microphytobenthos on the other groups of the system (Fig. 4). Primary producers provide a key food supply for filter feeders (second trophic level), which constitute the preys of higherorder consumers.

Total system throughput (Table 4) reached $9400 \mathrm{t} \cdot \mathrm{km}^{-2} \cdot$ year $^{-1}$, of this, $12 \%$ is devoted to consumption, $8 \%$ to respiration, $41 \%$ to flows to detritus and $39 \%$ to exports (equivalent to yield and/or net system production).

Total primary production/total biomass $\left(\mathrm{PP} / \mathrm{B}=25\right.$ year $\left.{ }^{-1}\right)$ and total primary production/respiration $(\mathrm{PP} / \mathrm{R}=6)$ had high values. The omnivory index of the MSMB model, of about 0.06, identifies the food web as very simple; consistently, the FCI is very low $(0.64 \%)$ and the Finn's mean path length very short (2.1; Table 4$)$.

\section{DISCUSSION}

The model developed in this study was mainly based on data collected from studies conducted on the MSMB during the reference year 2003. After that the biomass of predator groups targeted by fisheries was left to be estimated by the model, this Ecopath model was equilibrated. As (i) input data were based on in situ surveys, (ii) none of the EE values exceeds 1 (Christensen and Walters, 2004) and (iii) estimated annual productions $(\mathrm{B} \times \mathrm{P} / \mathrm{B})$ were realistic with regards to catches and fishing pressures for groups which biomasses are calculated from the mass-balance procedure, this model was considered as realistic. Even if this model is based on an annual mass-balance, and does not reproduce the large seasonal variations, and probable seasonal contrasted trophic situations, it can be used to analyse the system on this annual scale.

This model has highlighted the main features of the MSMB: a very high production, associated with a low efficiency of transfer from primary production to higher trophic levels, partly due to a large biomass of filter feeders not available for consumption within the system. Also, the system is profoundly impacted by the invasive mollusk Crepidula fornicata.

\subsection{A general description of the trophic web}

\subsubsection{Low rate of transfer of the high primary production in the trophic chain}

In spite of a moderate production of microphytobenthos, MSMB is highly productive, the primary production being essentially supported by phytoplankton, whose concentration remains high through the summer (Hoch and Gareau, 1998). As in coastal lagoons, the strong tidal currents in this bay enhance the production rate (Comin and Valiela, 1993), by injecting regenerated nutrients into the euphotic zone (Hoch and Garreau, 1998).

However, an adverse effect of hydrodynamics in the MSMB is that tidal currents lead to exchanges with adjacent shelf waters and to huge losses of organic matter via phytoplankton export (Le Pape and Menesguen, 1997). As a consequence, the primary production can not be 
fully exploited by the bay’s consumers (Le Pape et al., 1999; Rybarczyk et al., 2003; Riera, 2007).

\subsubsection{The large influence of filter feeders}

The model highlights the importance of filter feeders in the trophic network in the MSMB, which is locally called "filter feeders' bay." Such role for filter feeders frequently occurs in highly productive coastal systems, as high primary production results in higher food availability favorable to filter feeding (Le Pape et al., 1999; Grall and Chauvaud, 2002).

However, one of the specific feature of the MSMB is that a large proportion of these filter feeders consist of Crepidula fornicata: its consumption reaches more than $40 \%$ of consumptions at TL 2, but it is not exploited by human nor by the food chain ; hence, it represents a large trophic impasse (Fig. 3).

\subsection{A global evaluation of the system}

The model identified the MSMB as a highly productive ecosystem and the Leontief matrix routine demonstrated that it is largely controlled from the bottom-up. However, global indicators (high PP/B and PP/R, low omnivory and low Finn cycling index and mean path length) suggests that the MSMB ecosystem is immature, in line with Odum (1969), Finn (1976) and Ulanowicz (1986, 1995). Low maturity status is common in megatidal coastal and estuarine systems, as the bay of Somme (Rybarczyk et al., 2003), or the Seine estuary (Rybarczyk and Elkaim, 2003), with relation to the low rate of transfer of primary production (Le Pape and Menesguen, 1997). Even if it is sometimes difficult to compare different systems from different degree of compartments aggregation in models, very low values of cycling index in the MSMB reflect an especially immature system.

The immaturity of the MSMB trophic network may be explained, if partly, by the intensive human exploitation of the bay, through shellfish farming and fishing activities. Yields represent $15 \%$ of the net primary production in the MSMB, i.e., a high rate of exploitation (Pauly and Christensen, 1995; Christensen and Pauly, 1998), especially when the large losses of primary production due to hydrodynamic exchanges (Le Pape et al., 1999) are considered.

However, the immaturity status is also due to the high biomass of Crepidula fornicata, which represents $50 \%$ of the biomass at $\mathrm{TL}=2$, and $40 \%$ of the consumption of the primary production, but which causes a trophic impasse and reduces the efficiency of overall trophic interactions in the system.

In conclusion, the MSMB trophic network appears to be segmented in three trophic subsystems, partly disconnected (Fig. 3):

- A short shellfish farming chain (TL 2), whose trophic influence on the system is moderate;

- A short chain (TL 2), based on Crepidula fornicata, which consumes a large part of the, mainly planctonic, primary production (Riera, 2007);

- A residual 'natural' exploited system, with a high transfer efficiency.

\subsection{The determining influence of Crepidula fornicata}

Coastal and estuarine areas are among the most biologically-invaded systems in the world, especially by molluscs (Grosholz 2002; Reise et al., 2006), with grave consequences for the invaded ecosystems. Cloern (1982) demonstrated the large influence of the exotic clam Pomacorbula amurensis in San Francisco Bay, which now diverts to itself the major part of primary production. Ecological consequences of invasions into coastal habitats can affect the entire ecosystem (Grosholz 2002) and, in several cases, as in the San Francisco Bay after the introduction of P. amurensis (Bax et al. 2003), the collapse of fisheries. 
However, Crooks and Khim (1999) suggested that the effects of habitat structure changes could compensates for the effect of invasive species on food webs. Thus, Crepidula fornicata modifies physical characteristics of benthic habitats (1) by accumulating chain-shaped colonies which carpet the sea bottoms (Thieltges et al. 2003) and (2), as other filter feeding invasive species do (Daunys et al., 2006), by the excessive sedimentation associated with its excretion and by modification of hydrodynamics in the boundary layer flow (Ehrold et al., 1998). Such habitat changes have been demonstrated to alter the nursery function of coastal areas (Le Pape et al., 2004).

Reise et al. (2006), who reviewed the problem of introduced species in European coastal ecosystems, are globally less alarmist, asserting that there is no evidence that alien species generally impair biodiversity and ecosystem functioning. Similarly, Montaudouin and Sauriau (1999) found that biomass, abundance and species richness of benthic macrofauna were enhanced in the presence of Crepidula fornicata, whose shells increase the heterogeneity of the substrate (Attrill et al., 1996). MSMB hence appears as an inverse example, where the consequences of the massive invasion of slipper limpet appear very important with, as in the San Francisco Bay, a large (40 \%) diversion of the consumed primary production.

\subsection{Investigation of future changes in the system and management measures}

One aim of the PNEC program in the MSMB was to develop knowledge in order to create reliable tools for management. Since the present study is not predictive, the question of the future of the bay remains open. Possible scenarios include: (1) changes in shellfish farming distribution and intensity, and/or (2) changes in the distribution of Crepidula fornicata including those due to control measures. These changes could be in part simulated using Ecosim (Christensen and Walters, 2004), which simulated biomass dynamics based on parameters derived from the Ecopath model. However, this procedure implies the setting of a vulnerability rate to simulate the top-down versus bottom-up control; the problem is that the results are very sensitive to the vulnerability values chosen (Christensen and Walters, 2004). Without time series data, it was not possible to tune these parameters and the simulations will remain very sensitive to the initial settings, particularly the spatial biogeochemical dynamics. Nevertheless, additional mass-balance sub-models, as the one used to analyze the consumption of primary production by slipper limpets in the area covered by cultivated mollusks (cf. 3.2.2.) can provide informations on contrasted situations. This sub-model has allowed to demonstrate that the impact of the slipper limpet is still higher than this of farmed shellfish when farming areas only are taken into account. It would be possible to develop comparable sub-models to investigate other questions.

The next steps in this study should thus involve developing an alternative spatial biogeochemical dynamic model, taking into account the filtering pressure of mollusks. An alternative approach would consist in assembling suitable time series, taking into account possible changes in biomass and diet matrix, and also investigating the use of Ecospace, which also uses parameters from Ecopath (Pauly et al., 2000; Walters et al., 1998). 


\section{ACKNOWLEDGEMENTS}

We would like to thank (in France) G. Fontenelle (Agrocampus Rennes) who initiate this projetc, D. Nicolas (Agrocampus Rennes), for her contribution to the redaction and the numerous contributors in data collection: P. Berthou, M. Blanchard, D. Gerla, D. Latrouite, J. Mazurié and C. Trutski (IFREMER), E. Thiébaut (Université Pierre et Marie Curie - Paris VI, France), F. Olivier (Muséum National d'Histoire Naturelle, Dinard), A. Radureau and P. Lafaille (Université de Rennes) and J.P. Robin and B. Dubois (Université de Caen). The project which led to this contribution was funded by the French National program for coastal ecology (PNEC). This model is a follow-up of an Ecopath workshop held at the Agrocampus Rennes April 17-20, 2000, run by D. Pauly and G. Fontenelle. D. Pauly wishes to thank the Pew Charitable Trusts (Philadelphia, USA) funding through the Sea Around Us Project and M.L.D. Palomares for help with the manuscript. The authors are also grateful to the two anonymous referees for their pertinent comments on the draft version of the manuscript.

\section{REFERENCES}

Allen, R.R., 1971. Relation between production and biomass. Journal of the Fisheries Research board of Canada 28, 1573-1581.

Antunes, P., Santos, R., 1999. Integrated environmental management of the oceans. Ecological Economics 31, 215-226.

Attrill, M., Ramsay, P., Thomas, R., Trett, M., 1996. An estuarine biodiversity hot-spot. Journal of the Marine Biological Association UK 76, 161-175.

Balmford, A., Bruner, A., Cooper, P., Costanza, R., Farber, S., Green, R.E., Jenkins, M., Jefferiss, P., Jessamy, V., Madden, J., Munro, K., Myers, N., Naeem, S., Paavola, J., Rayment, M., Rosendo, S., Roughgarden, J., Trumper, K., Turner, R.K., 2002. Economic reasons for conserving wild nature. Science 297, 950-953.

Bax, N.A.W., Aguero, M., Gonzales; E., Geeves, W. 2003. Marine invasive alien species: a threat to global diversity. Marine Policy 27, 313-323.

Beck, M.W., Heck, K.L., Able, K.W., Childers, D.L. Eggleston, D.B., Gillanders, B. M., Halpern, B., Hays, C.G., Hostino, K., Minello, T.J., Orth, R.J. , Sheridan, P., Weinstein, M.P., 2001. The role of nearshore ecosystems as fish and shellfish nurseries. Bioscience 51, 633-641.

Blanchard, M., 1997. Spread of the slipper limpet (Crepidula fornicata) in Europe. Current state and consequences. Scientia Marina 61, 109-118.

Blanchard, M., Ehrhold, A., 1999. Cartographie et évaluation du stock de crépidule en baie du MontSaint-Michel. Haliotis 28, 11-20.

Christensen, V. 1995. A model of trophic interaction in the North Sea in 191, the year of the stomach. Dana 11, 1-28.

Christensen, V., Pauly, D., 1998. Changes in model of aquatic ecosystems approaching carrying capacity. Ecology Applications 8, 104-109.

Christensen, V., Walters, C.J., 2004. Ecopath with Ecosim, Methods, capabilities and limitations. Ecological Modelling 172, 109-139.

Cloern, J.E., 1982. Does the benthos control phytoplankton biomass in San Francisco Bay? Marine Ecology Progress Series 9, 191-202.

Comin, F.A., Valiela, I., 1993. On the control of phytoplankton abundance and production in coastal lagoons. Journal of Coastal Research 9, 895-906.

Costanza, R., D’Arge, R., De Groot, R., Farber, S., Grasso, M., Hannon, B., Limburg, K., Naeem, S., O’Neill, R.V., Paruelo, J., Raskin, R.G., Sutton, P., Van Den Belt, M., 1997. The value of the world's ecosystem services and natural capital. Nature 387, 253-260.

Costanza, R., 1999. The ecological, economic and social importance of the oceans. Ecological Economics 31, 199-213. 
Crooks, JA., Khim, H.S., 1999. Architectural vs. biological effects of a habitat-altering, exotic mussel, Musculista senhousia. Journal of Experimental Marine Biology and Ecology 240, 53-75.

Daunys, D., Zemlys, P., Olenin, S., Zaiko, A., Ferrari, C., 2006. Impact of the zebra mussel Dreissena polymorpha invasion on the budget of suspended material in shallow lagoon ecosystem. Helgoland Marine Research 60, 113-121.

Dauvin, J.C., 2000. The muddy find sand Abra alba - Melinna palmata community of the bay of Morlaix twenty years after the Amoco Cadiz oil spill. Marine Pollution Bulletin 40, 528-536.

Dubois, S., 2002. Biodiversity associated with Sabellaria alveolata (Polychaeta: Sabellariidae) reefs: effects of human disturbances. Journal of Marine Biologial Association UK 82, 817-826.

Dubois, S., Commito, J.A., Olivier, F., Retière, C. 2006. Effects of epibionts on Sabellaria alveolata (L.) biogenic reefs and their associated fauna in the Bay of Mont Saint-Michel. Estuarine, Coastal and Shelf Science 68, 635-646.

Ehrhold, A., Blanchard, M., Auffret, J.P., Garlan, T., 1998. The role of Crepidula proliferation in the modification of the sedimentary tidal environment in Mont-Saint-Michel Bay (The Channel, France). Comptes rendus de l'académie des sciences Série II - Fascicule A - Sciences de la terre et des planètes 327, 583-588.

Finn, J.T, 1976. Measures of ecosystem structures and function derived from analysis of flows. Journal of Theoretical Biology 56, 363-380.

Fulton, E.A., Smith, A.D.M., Johnson, C.R., 2003. Effect of complexity on marine ecosystem models. Marine Ecology Progress Series 253, 1-16.

Fulton, E.A., Smith, A.D., Punt, A.E., 2005. Which ecological indicators can robustly detect effects of fishing? ICES Journal of Marine Science 62, 540-551.

Grall, J., Chauvaud, L., 2002. Marine eutrophication and benthos: the need for new approaches and concepts. Global Change Biology 8, 813-830.

Grosholz, E. 2002. Ecological and evolutionary consequences of coastal invasions. Trends in Ecology and Evolution 17, 22-27.

Hoch, T., Garreau, P., 1998. Phytoplankton dynamics in the English Channel: a simplified threedimensional approach. Journal Marine Systems 16, 133-150.

Hugues, T.P., Bellwood, D.R., Folke, C., Steneck, R.S., Wilson, J., 2005. New paradigms for supporting the resilience of marine ecosystems. Trends in Ecology and Evolution 20, 380-386.

Kavanagh, P., Newlands, N., Christensen, V., Pauly, D., 2004. Automated parameter optimization for Ecopath ecosystem models. Ecological Modelling 172, 141-149.

Lafaille, P., Brosse, S., Feunteun, E., Baisez, A., Lefeuvre, J.C., 1998. Role of fish communities in particulate organic matter fluxes between salt marshes and coastal marine waters in the Mont Saint Michel Bay. Hydrobiologia 373\&374, 121-133.

Lafaille, P., Feunteun, E., Lefeuvre, J.C., 2000. Composition of fish communities in a European macrotidal salt marsh (the Mont Saint Michel Bay, France). Estuarine, Coastal and Shelf Science 51, 429-438.

Lefeuvre, J.C., Bouchard, V., 2002. From a civil engineering project to an ecological engineering project: an historical perspective from the Mont Saint Michel Bay (France). Ecological Engineering 18, 593-606.

Le Mao, P., Retière, C., Le Bec, C., Gerla, D.2004. Gérer un anthroposystème littoral à forte valeur patrimoniale : comment relever ce défi en baie du Mont Saint Michel ? Oceanis 30, 95-115.

Le Mao, P., Pasco, P.Y., Provost, S., 2006. Consommation de la macro-faune invertébrée benthique par les oiseaux d'eau en baie du Mont Saint Michel. Alauda, Revue internationale d'Ornithologie 74, 23-36.

Le Pape, O., Menesguen, A., 1997. Hydrodynamic prevention of eutrophication in the Bay of Brest (France). A modelling approach. Journal of Marine Systems 12, 171-186.

Le Pape, O., Jean, F., Menesguen, A., 1999. Pelagic and benthic model coupling, application to the Bay of Brest, a semi-enclosed zone of western Europe. Marine Ecology Progress Series, 189, 135147.

Le Pape, O., Desaunay, Y., Guerault, D., 2004. Influence of an exotic mollusc, the American slipper limpet (Crepidula fornicata, L.) on habitat suitability for the juvenile common sole (Solea solea, L.) in the Bay of Biscay (France). Marine Ecology Progress Series 277, 107-115. 
Lindeman, R.L., 1942. The trophic dynamic aspect of ecology. Ecology 23, 399-418.

Loomis, S.H., VanNieuwenhuyze, W., 1985. Sediment correlates to density of Crepidula fornicata (Linnaeus) in the Pataguanset River, Connecticut. Veliger 27, 266-272

Montaudouin, X (de), Sauriau., P.G., 1999. The proliferating Gastropoda Crepidula fornicata may stimulate macrozoobenthic diversity. Journal of the Marine Biological Association UK 79, 10691077.

Odum, E.P., 1969. The strategy of ecosystems development. Science 164, 262-270.

Pace, M., Cole, J., Carpenter, S., Kitchell, J.F., 1999. Trophic cascades revealed in diverse ecosystem. Trends in Ecology and Evolution 14, 483-488.

Palomares, M.L.D., Froese, R., Pauly, D., 1993. On traditional knowledge, fish and databases: a call for contributions. Bulletin of the Special Interest Group on Traditional Management and Knowledge, Department of Fisheries, South Pacific Commission (2), 17-19.

Pauly, D., Christensen, V., 1995. Primary production required to sustain global fisheries. Nature 374, 255-257.

Pauly, D., Christensen, V., Walters, C., 2000. Ecopath, Ecosim and Ecospace as tools for evaluating ecosystem impact of fisheries. ICES Journal of Marine Science 57, 697-706.

Perez-Espana, H., Arreguin-Sanchez, F., 2001. An inverse relationship between stability and maturity in modes of aquatic ecosystems. Ecological Modelling 145, 189-196.

Polovina, J.J, 1984. An overview of the Ecopath model. Fishbyte 2, 5-7.

Reise, K., Olenin, S., Thieltges, D.W., 2006. Are aliens threatening European aquatic coastal ecosystems? Helgoland Marine Research 60, 77-83.

Riera, P., 2007. Trophic subsidies of Crassostrea gigas, Mytilus edulis and Crepidula fornicata in the Bay of Mont Saint Michel (France): a $\delta^{13} \mathrm{C}$ and $\delta^{15} \mathrm{~N}$ investigation. Estuarine, Coastal and Shelf Science 72, 33-41.

Ropert, M., Dauvin, J.C., 2000. Renewal and accumulation of a Lanice conchilega (Pallas) population in the baie des Veys, western Bay of Seine. Oceanologica Acta 23, 529-546.

Rybarczyk, H., Elkaim, B., Ochs, L., Loquet, 2003. Analysis of the trophic network of a macrotidal ecosystem: the Bay of Somme (Eastern Channel). Estuarine, Coastal and Shelf Science 58, 405421.

Rybarczyk, H., Elkaim, B., 2003. An analysis of the trophic network of a macrotidal estuary: the Seine estuary (Eastern Channel, Normandy, France). Estuarine, Coastal and Shelf Science 58, 775-791.

Stanford, R., Pitcher, T.J., 2004. Ecosystem Simulations of the English Channel: Climate and Trade Offs. Fisheries Centre Fisheries Report, 12, The University of British Columbia, Vancouver, Canada, 103 p.

Thieltges, D.W., Strasser, M., Reise, K., 2003 The American slipper limpet Crepidula fornicata (L.) in the northern Wadden sea 70 years after its introduction. Helgolander Meeresunters 57, 27-33

Ulanowicz, R.E., 1986. Growth and development: ecosystem phenomenology. Springer Verlag, New York, 203 p.

Ulanowicz, R.E., Puccia, C.J., 1990. Mixed trophic impacts in ecosystems. Coenoses 5, 7-16.

Ulanowicz, R.E., Kay J.J., 1991. A computer package for the analysis of ecosystem flow networks. Environmental Software 6, 131-142.

Ulanowicz, R.E., 1995. The part whole relation in ecosystems. In: Patten, B.C., Jorgensen, S.E., Auerbach, S.I. (Eds.). Complex Ecology. Prentice-Hall, New Jersey, pp. 549-560.

Walters, C., Pauly, D., Christensen, V., 1998. Ecospace: prediction of mesoscale spatial patterns in trophic relationships of exploited ecosystems, with emphasis on the impacts of marine protected areas. Ecosystems 2, 539-554.

Zwarts, L., Ens, B.J., Goss-Custard, J.D., Hulscher, J.B., Le V. Dit Durell, S.E.A., 1996. Causes of variation in prey profitability and its consequences for the intake rate of the Oystercatcher Haematopus ostralegus. Ardea 84A, 229-26 


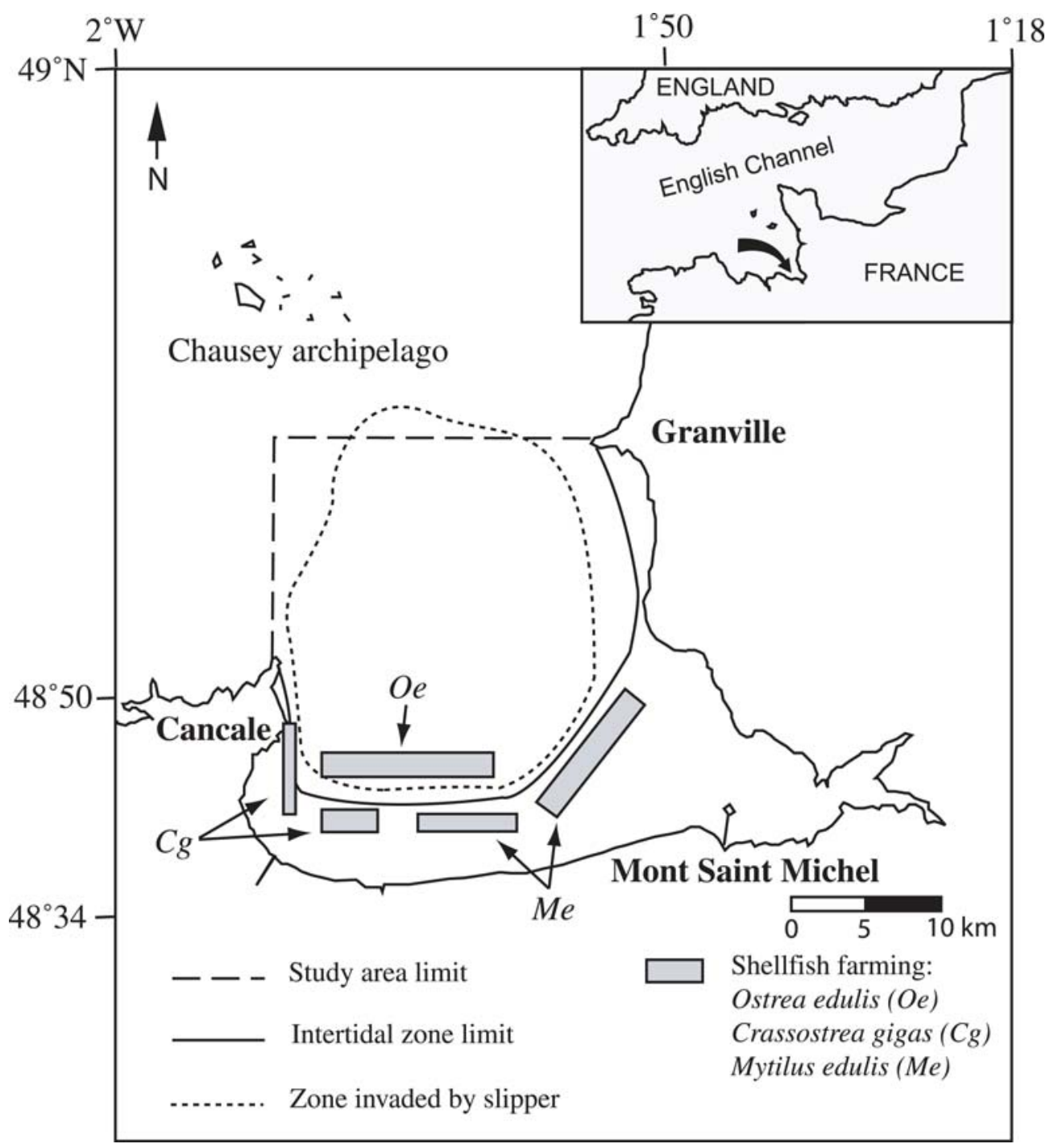

Figure 1. General location and details of the study area within the Mont Saint Michel Bay, France (geographic coordinates are in decimal degrees). 


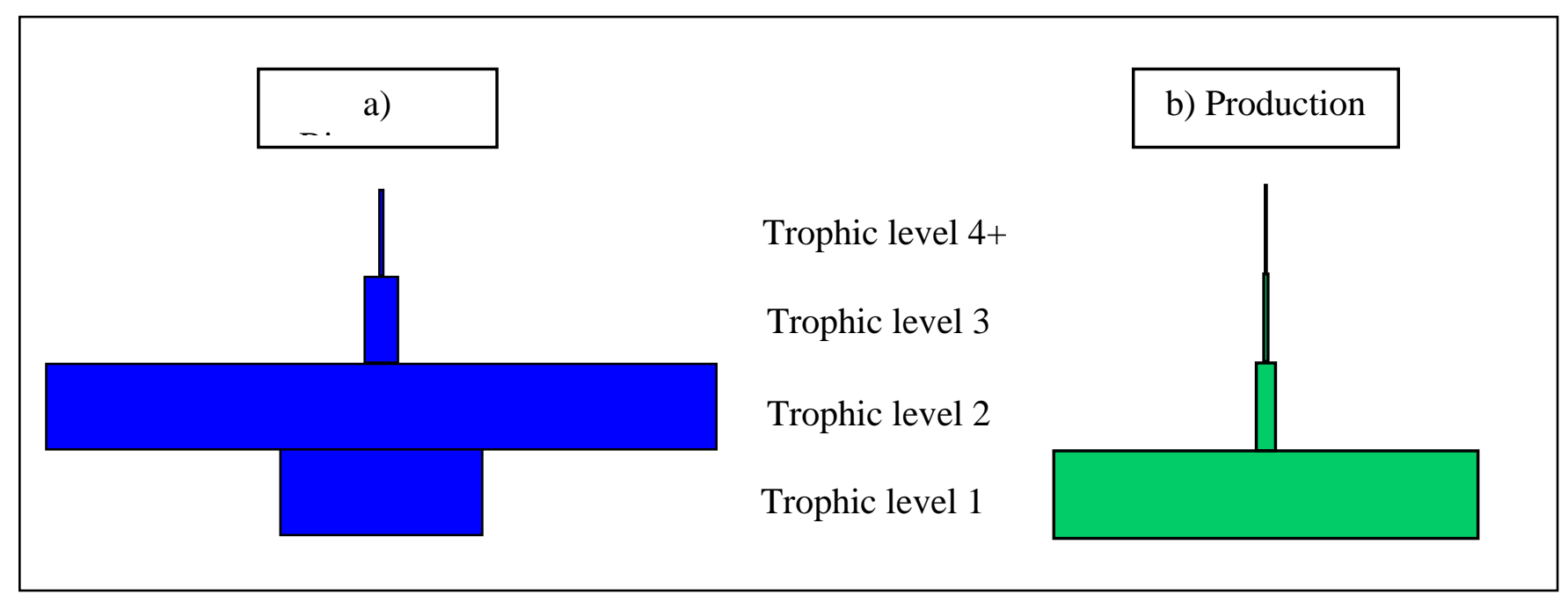

Figure 2. Pyramids of (a) biomass and (b) productivity characterizing the Mont Saint Michel Bay ecosystem (relative scales). 


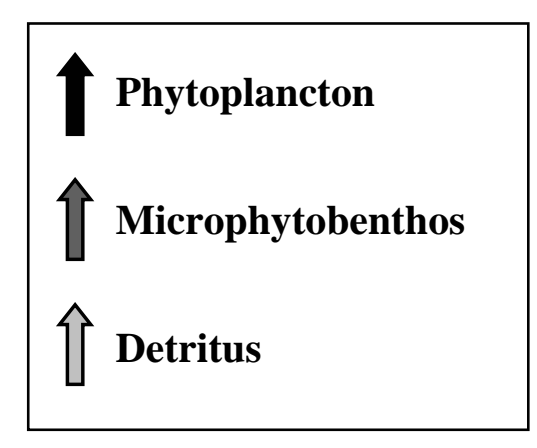

\section{Predators}

Trophic

level 4+
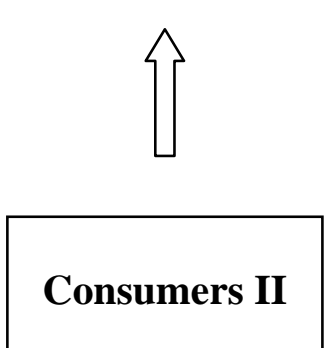

Trophic

level 3

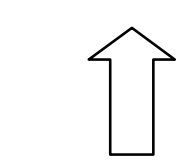

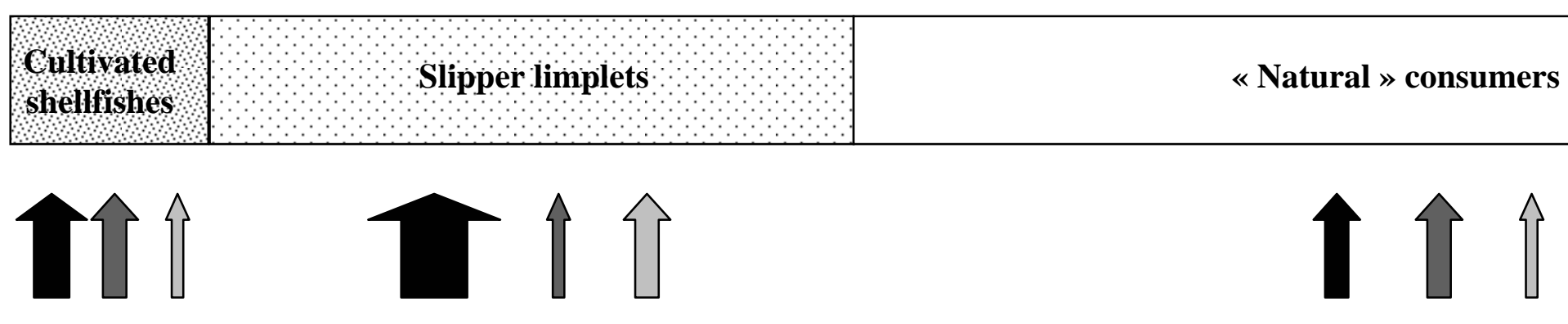

Trophic level 2

Figure 3. Pyramids of consumption characterizing the Mont Saint Michel bay with details on trophic level 2 (respective levels of consumption by farmed shellfish, slipper limpet and "natural" consumers, and origin of this consumption (primary production by phytoplankton or phytobenthos, or detritus) 
1 Birds

2 Marine mammals

3 Cephalopods

4 Big shellfishes

5 Adult fishes

6. Small fishes and juveniles of fished

7 Mullets

8 Zooplankton

9 Carnivorous and

necrophagous

macrobenthic fauna

10 Intertidal filter

feeders

11 Subtidal filter

feeders

12 Meiofauna

13 Slipper limpets

14 European flat oyster

15 Japanese oyster

16 Common mussel

17 Phytoplankton

18.Microphytobenthos

19 Detritus

20 Subtidal fishing

21 Intertidal fishing

22 Oyster culture

23 Mussel culture

24 Hunting

25 Dragging
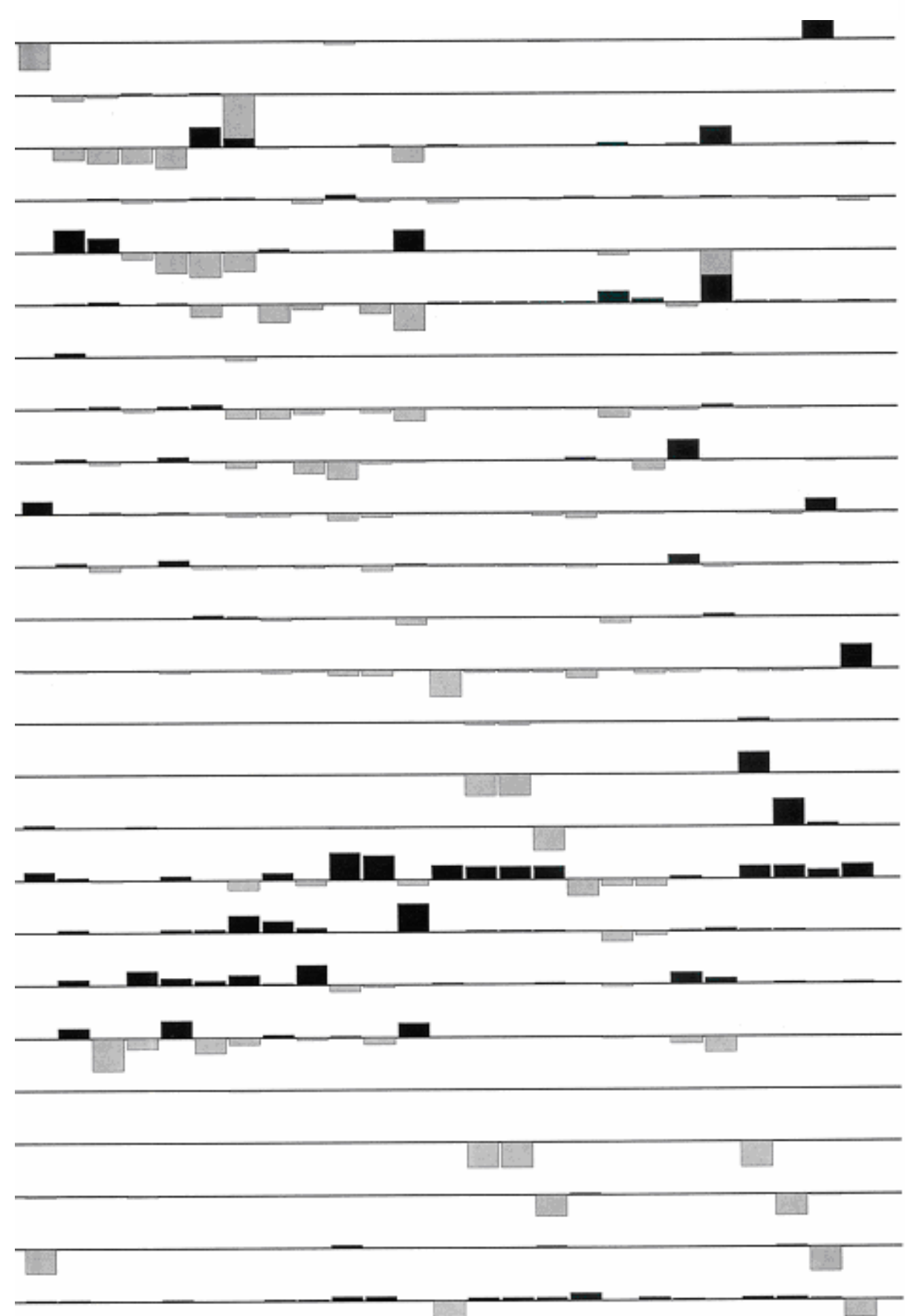

Figure 4. Mixed trophic impacts between groups of the Mont Saint Michel Bay ecosystem. Bars represent the direct and indirect trophic impacts that the groups lines have on the columns groups. Black bars indicate a positive impact and white bars a negative impact. The impacts are relative and comparable each others. 
Table 1. Input data values for the Mont Saint Michel Bay Ecopath model obtained mostly from the French national program of coastal environment on the Mont Saint Michel Bay (PNEC). The model refers to the year 2003, as most data used for its construction were based on sampling conducted in 2003. Choices of parameter values were also informed by the Feb. 17-20, 2000 Ecopath workshop conducted in the Agrocampus, Rennes (D. Pauly and G. Fontenelle, unpublished data)

\begin{tabular}{|c|c|c|c|c|}
\hline Trophic group & Biomass & production/biomass (P/B) & consumption/biomass $(\mathrm{Q} / \mathrm{B})$ & production/consumption (P/Q) \\
\hline Birds & Le Mao et al. (2006) & Stanford and Pitcher (2004) & Stanford and Pitcher (2004) & \\
\hline Marine mammals & $\begin{array}{l}\text { G. Gautier, DIREN Basse Normandie*, } \\
\text { (PNEC); C. Liret, Océanopolis (unpub. data) }\end{array}$ & Stanford and Pitcher (2004) & Stanford and Pitcher (2004) & \\
\hline Cephalopods & Model estimate & Stanford and Pitcher (2004) & Stanford and Pitcher (2004) & \\
\hline Large shellfishes & Model estimate & D. Latrouite, IFREMER (unpub. data) & Stanford and Pitcher (2004) & \\
\hline Adult fishes & Model estimate & Stanford and Pitcher (2004) & Stanford and Pitcher (2004) & \\
\hline Small and juvenile fishes & Model estimate & & Lafaille et al., 1998 & Palomares et al. (1993) \\
\hline Mullets & Model estimate & Stanford and Pitcher (2004) & Stanford and Pitcher (2004) & \\
\hline Zooplankton & QUADRIGE II database, IFREMER & Christensen (1995) & Christensen (1995) & \\
\hline $\begin{array}{l}\text { Carnivorous and necrophagous } \\
\text { macrobenthic fauna }\end{array}$ & Model estimate & Stanford and Pitcher (2004) & Stanford and Pitcher (2004) & \\
\hline Intertidal filter feeders & $\begin{array}{l}\text { J. Trigui and E. Thiebaut, Univ. Paris } 6 \\
\text { (PNEC); N. Toupoint, Museum National } \\
\text { d’Histoire Naturelle (unpub. data.); } \\
\text { Dubois (2002);Dubois et al., (2006) } \\
\text { Zwarts et al. (1996) }\end{array}$ & $\begin{array}{l}\text { Ropert, and Dauvin (2000); } \\
\text { Dauvin (2000) }\end{array}$ & & Stanford and Pitcher (2004) \\
\hline Subtidal filter feeders & $\begin{array}{l}\text { F. Olivier, MNHN (PNEC); } \\
\text { E. Thiebaut and C. Guichardière, Univ. } \\
\text { Paris } 6 \text { (PNEC); } \\
\text { Zwarts et al. (1996) }\end{array}$ & $\begin{array}{l}\text { Ropert and Dauvin (2000); } \\
\text { Dauvin (2000) }\end{array}$ & & Stanford and Pitcher (2004) \\
\hline Meiofauna & K. Seznec, Univ. Paris 6 (PNEC) & Le Loc’h (unpub. data) & & Le Loc’h (unpub. data) \\
\hline Slipper limpets & Blanchard and Ehrhold (1999) & Blanchard and Ehrhold (1999) & Blanchard and Ehrhold (1999) & \\
\hline European flat oyster & $\begin{array}{l}\text { Y. Thomas and J. Mazurié, IFREMER } \\
\text { (PNEC) }\end{array}$ & $\begin{array}{l}\text { Y. Thomas and J. Mazurié, } \\
\text { IFREMER (PNEC) }\end{array}$ & & Stanford and Pitcher (2004) \\
\hline Japanese oyster & $\begin{array}{l}\text { Y. Thomas and J. Mazurié, IFREMER } \\
\text { (PNEC) }\end{array}$ & $\begin{array}{l}\text { Y. Thomas and J. Mazurié, } \\
\text { IFREMER (PNEC) }\end{array}$ & & Stanford and Pitcher (2004) \\
\hline Common mussel & $\begin{array}{l}\text { Y. Thomas and J. Mazurié, IFREMER } \\
\text { (PNEC) }\end{array}$ & $\begin{array}{l}\text { Y. Thomas and J. Mazurié, } \\
\text { IFREMER (PNEC) }\end{array}$ & & Stanford and Pitcher (2004) \\
\hline Phytoplankton & QUADRIGE II database, IFREMER & C. Struski, IFREMER (PNEC) & & \\
\hline Microphytobenthos & D. Davoult, Univ. Paris 6 (PNEC.) & D. Davoult, Univ. Paris 6 (PNEC) & & \\
\hline
\end{tabular}

*Institutional affiliation of data providers (unpublished data) are all located in France 
Table 2. Input and calculated (in bold) parameters for the Ecopath model of the Mont Saint Michel Bay. Catches and biomasses are expressed in t.km-2 (fresh weight). The production/biomass (P/B) and consumption/biomass $(\mathrm{Q} / \mathrm{B})$ ratios are in year-1. The production/consumption (P/Q) ratio, trophic level (TL) and ecotrophic efficiency (EE) are dimensionless. Data in italics originate from 2003 studies of the French national program of coastal environment on the Mont Saint Michel Bay (PNEC). Values in bold are computed from the Ecopath with Ecosim software.

\begin{tabular}{lrrrrrrr}
\hline Trophic group & Catch & Troph & Biomass & P/B & Q/B & EE & P/Q \\
\hline Birds & 0.002 & $\mathbf{3 . 0 1}$ & 0.263 & 0.400 & 14.000 & $\mathbf{0 . 0 1 9}$ & $\mathbf{0 . 0 2 9}$ \\
Marine mammals & & $\mathbf{4 . 1 2}$ & 0.027 & 0.310 & 13.900 & $\mathbf{0 . 0 0 0}$ & $\mathbf{0 . 0 2 2}$ \\
Cephalopods & 0.480 & $\mathbf{3 . 7 9}$ & $\mathbf{0 . 2 3 0}$ & 2.5 & 15.000 & 0.900 & $\mathbf{0 . 1 6 7}$ \\
Large shellfishes & 0.450 & $\mathbf{2 . 6 9}$ & $\mathbf{1 . 7 6 7}$ & 0.500 & 4.000 & 0.900 & $\mathbf{0 . 1 2 5}$ \\
Adult fishes & 0.150 & $\mathbf{3 . 1 6}$ & $\mathbf{3 . 5 0 1}$ & 0.800 & 6.000 & 0.900 & $\mathbf{0 . 1 3 3}$ \\
Small and juvenile fishes & 0.160 & $\mathbf{2 . 8 2}$ & $\mathbf{1 . 0 8 8}$ & $\mathbf{6 . 6 0 0}$ & 22.000 & 0.900 & 0.300 \\
Mullets & 0.002 & $\mathbf{2 . 1 0}$ & $\mathbf{0 . 0 8 8}$ & 0.500 & 5.000 & 0.900 & $\mathbf{0 . 1 0 0}$ \\
Zooplankton & & $\mathbf{2 . 0 0}$ & 2.460 & 18.000 & 60.000 & $\mathbf{0 . 2 5 7}$ & $\mathbf{0 . 3 0 0}$ \\
Carnivorous and necrophagous & 3.000 & $\mathbf{2 . 0 8}$ & $\mathbf{1 3 . 6 1 5}$ & 1.300 & $\mathbf{6 . 5 0 0}$ & 0.900 & 0.200 \\
macrobenthic fauna & & & & & & & \\
Intertidal filter feeders & & $\mathbf{2 . 0 0}$ & 12.350 & 1.300 & $\mathbf{1 3 . 0 0 0}$ & $\mathbf{0 . 8 7 7}$ & 0.100 \\
Subtidal filter feeders & 1.500 & $\mathbf{2 . 0 0}$ & 6.450 & 1.300 & $\mathbf{1 3 . 0 0 0}$ & $\mathbf{0 . 8 0 8}$ & 0.100 \\
Meiofauna & & $\mathbf{2 . 0 0}$ & 0.700 & 10.000 & $\mathbf{5 0 . 0 0 0}$ & $\mathbf{0 . 3 4 8}$ & 0.200 \\
Slipper limpets & 3.050 & $\mathbf{2 . 0 0}$ & 91.100 & 0.300 & 4.500 & $\mathbf{0 . 1 4 0}$ & $\mathbf{0 . 0 6 7}$ \\
European flat oyster & 0.150 & $\mathbf{2 . 0 0}$ & 0.410 & 0.400 & $\mathbf{4 . 0 0 0}$ & $\mathbf{0 . 9 1 5}$ & 0.100 \\
Japanese oyster & 0.760 & $\mathbf{2 . 0 0}$ & 1.350 & 0.630 & $\mathbf{6 . 3 0 0}$ & $\mathbf{0 . 8 9 4}$ & 0.100 \\
Common mussel & 6.150 & $\mathbf{2 . 0 0}$ & 4.600 & 2.000 & $\mathbf{2 0 . 0 0 0}$ & $\mathbf{0 . 8 5 4}$ & 0.100 \\
Phytoplankton & & $\mathbf{1 . 0 0}$ & 24.055 & 166.000 & - & $\mathbf{0 . 1 6 6}$ & - \\
Microphytobenthos & & $\mathbf{1 . 0 0}$ & 16.000 & 27.000 & - & $\mathbf{0 . 3 8 2}$ & - \\
\hline
\end{tabular}


Table 3. Predator-prey matrix of the ecosystem in the Mont Saint Michel Bay. Data in italics originate from 2003 studies of the French national program of coastal environment on the Mont Saint Michel Bay (PNEC).

\begin{tabular}{|c|c|c|c|c|c|c|c|c|c|c|c|c|c|c|c|c|}
\hline Prey/ Predator & 1 & 2 & 3 & 4 & 5 & 6 & 7 & 8 & 9 & 10 & 11 & 12 & 13 & 14 & 15 & 16 \\
\hline \multicolumn{17}{|l|}{ 1. Birds } \\
\hline \multicolumn{17}{|l|}{ 2. Marine mammals } \\
\hline 3. Cephalopods & & 0.1 & & & & & & & & & & & & & & \\
\hline 4. Large shellfishes & & & 0.1 & & & & & & 0.1 & & & & & & & \\
\hline 5. Adult fishes & & 0.8 & 0.6 & 0.1 & & & & & 0.2 & & & & & & & \\
\hline 6. Small and juvenile fishes & & & & & 0.3 & & & & 0.1 & & & & & & & \\
\hline 7. Mullets & & 0.1 & & & & & & & & & & & & & & \\
\hline 8. Zooplankton & & & & & 0.2 & 0.3 & & & & & & & & & & \\
\hline $\begin{array}{l}\text { 9. Carnivorous and necrophagous macrobenthic } \\
\text { fauna }\end{array}$ & 0.15 & & 0.3 & 0.3 & 0.2 & 0.2 & & & & & & & & & & \\
\hline 10. Intertidal filter feeders & 0.6 & & & & 0.1 & 0.2 & & & 0.05 & & & & & & & \\
\hline 11. Subtidal filter feeders & & & & 0.1 & 0.1 & 0.1 & & & & & & & & & & \\
\hline 12. Meiofauna & & & & & & 0.1 & 0.1 & & & & & & & & & \\
\hline 13. Slipper limpets & & & & 0.1 & & & & & & & & & & & & \\
\hline \multicolumn{17}{|l|}{ 14. European flat oyster } \\
\hline 15. Japanese oyster & & & & & & & & & & & & & & & & \\
\hline 16. Common mussel & 0.25 & & & 0.1 & & & & & & & & & & & & \\
\hline 17. Phytoplankton & & & & & & & & 0.4 & & 0.8 & 0.8 & & 0.8 & 0.8 & 0.8 & 0.8 \\
\hline 18. Microphytobenthos & & & & & & & 0.5 & 0.4 & 0.15 & 0.1 & 0.1 & 0.8 & 0.05 & 0.15 & 0.15 & 0.1 \\
\hline 19. Detritus & & & & 0.3 & 0.1 & 0.1 & 0.4 & 0.2 & 0.4 & 0.1 & 0.1 & 0.2 & 0.15 & 0.05 & 0.05 & 0.1 \\
\hline
\end{tabular}


Table 4. Summary statistics for the Mont Saint Michel bay model.

\begin{tabular}{lcc}
\hline Parameter & Units & Value \\
\hline Sum of all consumption & $\mathrm{t} \cdot \mathrm{km}^{-2} \cdot \mathrm{year}^{-1}$ & 1090 \\
Sum of all exports & $\mathrm{t} \cdot \mathrm{km}^{-2} \cdot \mathrm{year}^{-1}$ & 3700 \\
Sum of all respiratory flows & $\mathrm{t} \cdot \mathrm{km}^{-2} \cdot \mathrm{year}^{-1}$ & 730 \\
Sum of flows into detritus & $\mathrm{t} \cdot \mathrm{km}^{-2} \cdot \mathrm{year}^{-1}$ & 3880 \\
Total system throughput & $\mathrm{t} \cdot \mathrm{km}^{-2} \cdot \mathrm{year}^{-1}$ & 9400 \\
Sum of all production & $\mathrm{t} \cdot \mathrm{km}^{-2} \cdot \mathrm{year}^{-1}$ & 4570 \\
Mean trophic level of catch & & 2.11 \\
Gross efficiency (catch/net P.P) & & 0.00358 \\
Calculated total net primary production & $\mathrm{t} \cdot \mathrm{km}^{-2} \cdot \mathrm{year}^{-1}$ & 4430 \\
Total primary production/total respiration & & 6.1 \\
Net system production & $\mathrm{t} \cdot \mathrm{km}^{-2} \cdot \mathrm{year}^{-1}$ & 3700 \\
Total primary production/total biomass & & 24.6 \\
Total biomass/total throughput & & 0.019 \\
Total biomass (excluding detritus) & $\mathrm{t} \cdot \mathrm{km}^{-2}$ & 180 \\
Total catches & $\mathrm{t} \cdot \mathrm{km}^{-2} \cdot \mathrm{year}^{-1}$ & 15.9 \\
Connectance index & & 0.17 \\
System omnivory index & & 0.058 \\
Finn cycling index & & 0.64 \\
Finn mean path length & & 2.1 \\
\hline
\end{tabular}

